\title{
. . Preface to the Fourth Paperback Printing . .
}

Re-reading a book I wrote thirty years ago-my first—provides me with a time-walking sensation. The author was young - absurdly young, to judge from his photograph on the original jacket-whereas I am a grandfather and old enough to see the succession of things. I scarcely know the author, so great is the time gulf between us. He strove enthusiastically to finish a doctoral dissertation and commence a college teaching career in the Golden West, whereas I contemplate a not-too-distant retirement in my native Texas.

What explains the durable appeal of the young author's little book, an appeal that kept it in print for a quarter of a century and now prompts its reissue? I do not really know, but permit me a guess or two. First, German Seed in Texas Soil benefits from dealing with that most basic of dramas: people on the land seeking to wrest a living directly from the earth, arguably the only legitimate human endeavor. When that land is new and strange to them, reached only after an arduous journey across the sea, the drama becomes more intense. Moreover, these were my own people; this my own land. The Stammvater of my line, the Saxon peasant Ernst Jordan, came to "the rim of the desert" a century and a half ago, put down deep roots, and sired an enormous family. Two years ago we buried my father near Ernst's grave, and both lie within sight of the ancestral log house. Perhaps my attachment to these hardy Germans and to the beautiful, if demanding, land they settled comes through to the reader. I hope so.

The book also appeared at a pivotal time in German-American history. By the middle 1960s the stigma of being German was fading, yielding to a much older sense of pride. In addition, German Seed anticipated a truth about Texas and the United States in general that only gradually became evident-that the "melting pot" was pure sociological nonsense. We Americans are not becoming one people and will always remain many. Ethnic groups acculturate, as these Teutons did, but they endure. America is a mosaic, not a blend.

Whatever the reason for the book's success, I am honored and flattered that it has been deemed worthy of a new edition close to the dawn of a new century.

T. G. J. June 1993 
THIS PAGE INTENTIONALLY LEFT BLANK 